Tersedia Online di http://journal2.um.ac.id/index.php/jmsp/

ISSN Online : 2541-4429

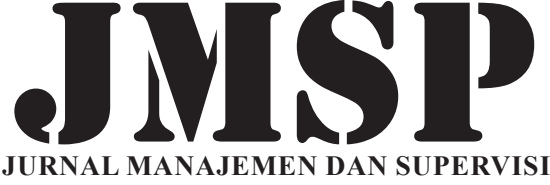

PENDIDIKAN

\title{
ANALISIS SISTEM KEPELATIHAN DI IKIP BUDI UTOMO MALANG DITINJAU DARI CRITICAL EVENT MODEL LEONARD NADLER
}

\author{
Sudari; Iskandar Zulkarnaen \\ IKIP Budi Utomo, Jalan Simpang Arjuno 14B Malang Jawa Timur Indonesia \\ sudarielyusufi@gmail.com
}

\begin{abstract}
This research aims to describe the training design held at IKIP Budi Utomo Malang in terms of CEM Leonard Nadler, to identify the strength and weakness of the training design held at IKIP Budi Utomo Malang in terms of CEM Leonard Nadler, and discovering the causes of strength and weakness of the training design held at IKIP Budi Utomo in terms of CEM Leonard Nadler. This research method uses a qualitative research approach. The results of this research indicate that the training design prepared at IKIP Budi Utomo Malang in accordance with the nine components determined by Leonard Nadler in CEM.
\end{abstract}

Keyword: system, coaching, critical event model

\begin{abstract}
Abstrak: Penelitian ini bertujuan mendeskripsikan desain pelatihan yang dilaksanakan di IKIP Budi Utomo Malang ditinjau dari CEM Leonard Nadler, untuk mengidentifikasi kekuatan dan kelemahan desain pelatihan yang dilaksanakan di IKIP Budi Utomo malang ditinjau dari CEM Leonard Nadler, serta menemukan faktor penyebab kekuatan dan kelemahan desain pelatihan yang dilaksanakan di IKIP Budi Utomo ditinjau dari CEM Leonard Nadler. Metode penelitian ini menggunakan pendekatan penelitian kualitatif. Hasil penelitian ini menunjukkan bahwa desain pelatihan yang disusun di IKIP Budi Utomo Malang sesuai dengan sembilan komponen yang ditetapkan oleh Leonard Nadler dalam CEM. Kekuatan: sistematika desain yang disusun di IKIP Budi Utomo Malang sesuai dengan pola pikir CEM Leonard Nadler.
\end{abstract}

Kata Kunci: sistem, kepelatihan, critical event model

Penyelenggaraan pendidikan tinggi membutuhkan Sumber Daya Manusia (SDM) yang memiliki kompetensi unggul. Perguruan tinggi harus menempuh berbagai cara untuk mendapatkan SDM yang memiliki kualitas tinggi, etos kerja produkif, keterampilan dan kreativitas, profesionalisme, disiplin, mampu menguasai dan mengembangkan teknologi pendidikan. Salah satu tawaran solutif melalui program pendidikan dan pelatihan. Dengan pelatihan diharapkan mampu meningkatkan performa kerja SDM perguruan tinggi (AECT, 2004; ASTD, 2008; Boise State University, 2008; Burkhardt, 2009). IKIP Budi Utomo Malang telah melaksanakan berbagai pelatihan seperti pelatihan PEKERTI, pelatihan SPMI internal, pelatihan penulisan proposal penelitian hibah, pelatihan e-learning, pelatihan kewirausahaan, pelatihan kepariwisataan, pelatihan penulisan jurnal ilmiah, pelatihan-pelatihan keolahragaan, pelatihan penyusunan bahan ajar khusus untuk dosen, pelatihan penyusunan PTK dan inovasi pembelajaran khusus untuk mahasiswa.

Sehubungan dengan seringnya dilaksanakan pelatihan-pelatihan di IKIP Budi Utomo Malang sebagai upaya peningkatan kualitas SDM dosen dan penguatan keterampilan mengajar bagi mahasiswa maka desain dan pelaksanaan pelatihan yang efektif menjadi suatu kebutuhan. Nadler menetapkan beberapa komponen atau variabel penting dinamakan Critical Events yang secara sistematikanya merupakan pola pikir dalam menyusun program pelatihan. Pola pikir tersebut dinamakan Critical Events Model (CEM). Critical Events Model (CEM) dapat dipergunakan sebagai acuan oleh desainer program pelatihan dengan penyesuaian terhadap situasi dan kondisi.

Nadler (1982) mengemukakan bahwa suatu model desain program pelatihan diperlukan oleh seorang desainer pelatihan untuk mengembangkan suatu pelatihan. Critical Events Model (CEM) merupakan suatu pendekatan model dalam penyusunan program pelatihan bagi tenaga kerja organisasi 
untuk menanggulangi masalah atau memenuhi kebutuhan organisasi. Komponen-komponen Critical Events Model (CEM) yang ditetapkan oleh Leonard Nadler secara berurutan: (1) identifikasi kebutuhan organisasi; (2) spesifikasi performa pekerjaan; (3) identifikasi kebutuhan pembelajar; (4) penetapan tujuan pelatihan; (5) penyusunan kurikulum; (6) penetapan strategi pembelajaran; (7) penetapan sumbersumber pelatihan; dan (8) persiapan pelaksanaan pelatihan.

Di setiap tahapan tersebut, Nadler (1982) menyisipkan kegiatan evaluasi dan umpan balik. Evaluasi dan umpan balik tersebut penting dalam Critical Events Model (CEM), sehingga satu tahap desain pelatihan tidak dapat dilanjutkan ke tahapan-tahapan berikutnya jika evaluasi dan umpan balik tidak atau belum dilaksanakan. Salah satu kajian penelitian yang relevan dengan desain program pelatihan berdasarkan Critical Events Model adalah penelitian Dunning (2007), menganalisis kebutuhan pelatihan dan mengembangkan pelatihan berbasis kinerja. Pendekatan tersebut digunakan dalam kelas pelatihan bagi desainer dan pengelola pelatihan. Pendekatan didasarkan pada analisis masalah kinerja dan desain sistem pembelajaran (instructional design system).

Penelitian yang relevan dengan Desain Program Pelatihan berdasarkan Critical Events Model juga penelitian yang dilakukan oleh Smith (2009), salah satu relevansinya dan yang dikembangkan dalam Critical Events Model (CEM) adalah pada Vocational Education and Training System (VET) digunakan baik pada organisasi diklat pemerintah maupun swasta, konsep paket-paket pelatihan (training packages) yang mencakup kompetensi-kompetensi yang diperlukan tiap unit kerja, seperti yang dibangun dalam CEM. Menarik untuk dilakukan penelitian bagaimana desain pelatihan yang dilaksanakan di IKIP Budi Utomo Malang ditinjau dari Critical Events Model (CEM) Leonard Nadler, kekuatan dan kelemahan desain pelatihan yang dilaksanakan di IKIP Budi Utomo Malang ditinjau dari Critical Events Model (CEM) Leonard Nadler, faktor kekuatan dan kelemahan desain pelatihan yang dilaksanakan di IKIP Budi Utomo Malang.

\section{METODE}

Penelitian ini menggunakan pendekatan kualitatif yaitu suatu prosedur penelitian yang digunakan untuk mendeskripsikan perilaku orang, peristiwa, atau tempat tertentu secara rinci dan mendalam (Denzin \& Lincoln, 2009). Penelitian ini, mendeskripsikan tahapan-tahapan desain program pelatihan yang didesain oleh unit P2SDM dan unit P3G IKIP Budi Utomo Malang dengan menggunakan Critical Events Model (CEM) yang dikembangkan oleh Leonard Nadler, mengidentifikasi kekuatan dan kelemahan desain program pelatihan ditinjau dari teori Critical Events Model (CEM) yang dikembangkan oleh Leonard Nadler, dan mengidentifikasi faktor penyebab kekuatan dan kelemahannya desain program pelatihan. Penelitian dilaksanakan di IKIP Budi Utomo Malang.

Data dalam penelitian kualitatif ini adalah berupa kata-kata yang dikumpulkan melalui observasi, wawancara, intisari dokumen dan rekaman. Sumber data yang digunakan adalah data primer dan data sekunder. Data primer diperoleh berasal dari pimpinan unit kepegawaian dan keuangan, pimpinan unit P2SDM bersama tim dan pimpinan unit P3G bersama tim, pimpinan unit penjaminan mutu, panitia pelatihan, dosen, dan mahasiswa. Data sekunder adalah sumber yang tidak langsung memberikan data kepada pengumpul data, misalnya melalui kepala TU dan staf, serta dokumen terkait dengan penelitian.

Pengumpulan data penelitian ini menggunakan wawancara, observasi dan dokumentasi. Teknik utama dalam pengumpulan data penelitian ini adalah wawancara dan dokumentasi, sedangkan observasi menjadi teknik pendukung. Wawancara yang digunakan adalah wawancara terbuka (open-ended) yang tidak sepenuhnya menuntut keteraturan (Denzin \& Lincoln, 2009). Panduannya hanya berisi garisgaris besar dan dilakukan dengan tatap muka (face to face). Wawancara dilakukan terhadap kepala unit P2SDM dan kepala unit P3G bersama staf atau tim desainer mendapatkan data tentang identifikasi kebutuhan organisasi, spesifikasi performa pekerjaan, identifikasi kebutuhan pembelajar, penetapan tujuan pelatihan, penyusunan kurikulum, dan penetapan strategi pembelajaran. Wawancara untuk menemukan data tentang penetapan sumber-sumber pelatihan dan penyiapan pelaksanaan pelatihan dilakukan terhadap tim desainer dan panitia. 
Tahapan desain program pelatihan yang diamati oleh peneliti hanya pada tahapan penetapan sumber-sumber pelatihan dan tahapan persiapan pelaksanaan pelatihan. Program pelatihan yang dipilih untuk diamati adalah program pelatihan peningkatan SDM Dosen dan program pelatihan penguatan keterampilan mengajar bagi mahasiswa semester akhir yang didesain sepenuhnya oleh IKIP Budi Utomo Malang melalui unit P2SDM dan unit P3G bersama staf atau tim desainer. Penelitian ini juga memanfaatkan dokumen-dokumen untuk mengumpulkan data. Dokumen diperoleh dari kepala unit kepegawaian dan keuangan, kepala unit P2SDM dan unit P3G bersama staf atau tim desainer, kepala unit penjaminan mutu, dan panitia program pelatihan. Dokumentasi yang digunakan dalam penelitian antara lain berupa laporan pelatihan tahun sebelumnya, catatan, dan materi atau kurikulum.

Data penelitian dianalisis menggunakan model Miles dan Huberman yang disunting oleh Denzin \& Lincoln (2009) melalui reduksi data, penyajian data, dan menarik kesimpulan atau verifikasi. Pertama, data dikumpulkan dari hasil wawancara, pengamatan, maupun analisis dokumen yang berkaitan dengan kegiatan mendesain program pelatihan di unit P2SDM dan unit P3G IKIP Budi Utomo Malang. Data-data tersebut kemudian direduksi dengan menggunakan indikator desain program pelatihan berdasarkan teori Critical Events Model (CEM) yang dikembangkan oleh Leonard Nadler. Data yang terkumpul diklasifikasi berdasarkan tahapan-tahapan yang ada dalam Critical Events Model (CEM) yang dikembangkan oleh Leonard Nadler, apakah termasuk tahapan identifikasi kebutuhan organisasi, spesifikasi performa pekerjaan, identifikasi kebutuhan pembelajar, penetapan tujuan pelatihan, penyusunan kurikulum, penetapan strategi pembelajaran, penetapan sumber-sumber daya pelatihan, atau persiapan pelaksanaan pelatihan.

Peneliti dalam pelaksanaan pengecekan keabsahan data mengacu pada kriteria pengecekan yang diungkapkan oleh Denzin \& Lincoln (2009), yaitu: (1) derajat kepercayaan (credibility); (2) keteralihan (transferability); (3) kebergantungan (dependability); dan (4) kepastian (confirmability). Data penelitian ini dianalisis menggunakan model Miles dan Huberman yang disunting oleh Denzin \& Lincoln (2009) melalui reduksi data, penyajian data, dan menarik kesimpulan atau verifikasi. Pertama, data dikumpulkan dari hasil wawancara, pengamatan, maupun analisis dokumen yang berkaitan dengan kegiatan mendesain program pelatihan pada unit P2SDM dan unit P3G IKIP Budi Utomo Malang. Data tersebut kemudian direduksi dengan menggunakan indikator desain program pelatihan berdasarkan Critical Events Model (CEM) yang dikembangkan oleh Leonard Nadler.

Setelah data desain program pelatihan dikelompokkan, maka dilanjutkan dengan mengkategorisasi data mana yang memberikan jawaban positif dan data mana yang merespon secara negatif terhadap indikator desain program pelatihan ditinjau dari Critical Events Model (CEM) yang dikembangkan oleh Leonard Nadler. Data positif dikategorikan sebagai desain program pelatihan yang kuat, data yang menunjukkan fakta tidak sesuai dengan Critical Events Model (CEM) yang dikembangkan oleh Leonard Nadler dikategorikan sebagai desain program pelatihan yang lemah. Masing-masing data desain yang kuat maupun yang lemah dianalisis berdasarkan alasan-alasan yang melatarbelakangi. Setelah data terkelompok, data disajikan dalam suatu deskripsi yang disesuaikan dengan tahapan Critical Events Model (CEM) yang dikembangkan oleh Leonard Nadler. Langkah terakhir adalah penarikan kesimpulan yang dilakukan dengan menjawab secara singkat inti dari pertanyaan-pertanyaan dalam penelitian ini.

\section{HASIL DAN PEMBAHASAN}

\section{Desain Pelatihan di IKIP Budi Utomo ditinjau dari Critical Event Model Leonard Nadler}

Penyusunan desain pelatihan bahan ajar bagi dosen muda, dan pelatihan penyusunan PTK serta inovasi pembelajaran bagi mahasiswa semester akhir dilingkungan IKIP Budi Utomo Malang di desain dan dilaksanakan oleh unit P2SDM dan unit P3G. Penyusunan desain pelatihan secara berurutan mengikuti langkah-langkah Critical Events Model (CEM) yang dikembangkan oleh Leonard Nadler sebagai berikut:

\section{Tahap 1 Identifikasi Kebutuhan Organisasi}

Identifikasi kebutuhan organisasi merupakan langkah pertama dari tahapan-tahapan Critical Events 
Model (CEM) yang ditetapkan oleh Leonard Nadler. Berdasarkan hasil wawancara peneliti dengan bapak $\mathrm{Hr}$ dan ibu En menunjukan bahwa yang mendesain pelatihan pengembangan dosen adalah pimpinan unit P2SDM bersama tim, sementara yang mendesain pelatihan PTK, inovasi pembelajaran untuk mahasiswa adalah pimpinan unit P3G bersama tim. Kedua unit tersebut telah mendesain pelatihan sesuai kebutuhan lembaga, kebutuhan dosen, dan kebutuhan mahasiswa.

Tahap identifikasi kebutuhan dilakukan untuk kepentingan penetapan jenis pelatihan yang menjadi skala prioritas kebutuhan lembaga, dosen dan mahasiswa. Hasil penelitian di atas sesuai dengan teori Critical Events Model (CEM) yang dikembangkan oleh Nadler (1982) bahwa tahapan identifikasi kebutuhan organisasi bertujuan untuk mengungkap kebutuhan organisasi apakah pelatihan sebagai solusi atau tidak dalam memenuhi kebutuhan organisasi.

\section{Tahap 2 Tahap Spesifikasi Pelaksanaan Tugas}

Hasil penelitian menunjukkan bahwa tim desainer P2SDM melakukan pemetaan kebutuhan ketrampilan dosen dan mengelompokkannya sesuai jenis pelatihan, demikian juga tim desainer P3G melakukan pemetaan kebutuhan ketrampilan mahasiswa dan mengelompokkannya sesuai jenis pelatihan. Di akhir tahapan ini tim desainer melakukan proses evaluasi dan umpan balik. Adapun bentuk evaluasi melalui rapat bersama para pimpinan, umpan balik terhadap mahasiswa dilakukan dalam bentuk sosialisasi dan sebaran angket.

Hasil penilitian di atas sesuai dengan Critical Events Model (CEM) yang dikembangkan oleh Nadler (1982), bahwa tahapan specify job performance ini bertujuan untuk menetapkan kinerja yang diharapkan dari orang yang ditugasi mengerjakan pekerjaan yang telah ditetapkan. Desainer harus dapat menentukan sumber data dan informasi yang dapat dipercaya dalam menentukan job performance (Furjanic \& Trotman, 2009; Goldstein \& Ford, 2002; Gusdorf, 2009). Metode yang dapat digunakan dalam pengumpulan data bisa melalui quistionaire, interviev, meeting, penelitian pustaka observasi, critical insident, dan trad-off situation. Di akhir tahapan ini, desainer harus dapat mengambil keputusan dengan menjawab pertanyaan-pertanyaan berikut: Apakah masih ada kaitannya dengan masalah pelatihan? Apakah ada kaitannya dengan kinerja? perlukah pertimbangan diberikan kepada beberapa alternatif? Apakah ada waktu untuk melaksanakan pelatihan? Apabila desainer yakin terhadap keputusannya, maka dilanjutkan ke even identify learning need.

\section{Tahap 3 Tahap Identifikasi Kebutuhan Pembelajar}

Berdasarkan hasil penelitian ditemukan beberapa jenis pelatihan yang ditetapkan sesuai skala prioritas kebutuhan dosen dan mahasiswa. Pelatihan yang menempati prioritas utama adalah pelatihan penyusunan bahan ajar yang diperuntukkan bagi dosen muda, dan pelatihan penyusunan PTK serta inovasi pembelajaran bagi mahasiswa semester akhir. Strategi mengidentifikasi kebutuhan pembelajar yang dilakukan oleh tim desainer P2SDM dengan cara mensosialisasikan penyusunan bahan ajar, hal yang sama juga dilakukan oleh tim desainer P3G yakni dengan cara mensosialisasikan jenis pelatihanpelatihan secara berjenjang seperti PTK, pelatihan inovasi pembelajaran, microteaching, dan PPL. Di akhir tahapan ini baik tim desainer P2SDM maupun tim desainer P3G melakukan proses evaluasi melalui rapat koordinasi bersama unit penjaminan mutu institut, dan melakukan umpan balik dengan mahasiswa melalui sebaran angket.

Hasil penilitian di atas sesuai dengan teori Critical Events Model (CEM) yang dikembangkan oleh Nadler (1982) mengungkapkan bahwa dalam mengidentifikasi kebutuhan pembelajar dapat dilakukan melalui pengumpulan data kebutuhan pembelajar, menganalisis kebutuhan pembelajar, mengevaluasi serta melakukan umpan balik. Watson \& Reigeluth (2001) menguatkan bahwa analisis kebutuhan pembelajar sangat berkaitan dengan orang-orang yang membutuhan pelatihan dan pelatihan yang dibutuhkan. Jika calon peserta pelatihan ingin meningkatkan performa kerja, maka pengetahuan apa saja yang sekiranya perlu dikembangkan (Ivancevich, 2008; Morrison, dkk., 2011; Noe, dkk., 2000).

\section{Tahap 4 Penetapan Tujuan}

Tujuan pelatihan pada umumnya dapat menentukan keberhasilan suatu pelatihan. Berdasarkan hasil wawancara dan dokumentasi menunjukkan bahwa tujuan pelatihan dirumuskan secara sepsifisik disesuaikan dengan jenis pelatihan yang di tetapkan, serta didasarkan pada keterampilan-keterapilan yang 
harus dimiliki oleh dosen dan mahasiswa. Rumusan tujuan pelatihan penyusunan bahan ajar diantaranya adalah memberi bekal dosen supaya mampu menulis modul atau bahan ajar sendiri, membantu mahasiswa dalam memperoleh alternatif bahan ajar disamping buku-buku teks yang terkadang sulit mendapatkannya, memudahkan dosen dalam melaksanakan perkuliahan. Di akhir tahapan ini dilakukan proses evaluasi dan umpan balik.

Proses evaluasi melalui rapat bersama, umpan balik melalui sebaran angket. Dalam teori Critical Events Model (CEM) yang dikembangkan oleh Leonard Nadler tujuan pelatihan pada dasarnya adalah suatu pernyataan tentang apa hasil yang ingin dicapai dalam pelaksanaan suatu pelatihan. Tujuan yang ditetapkan tentu berkaitan dengan upaya organisasi dalam menanggulangi masalah yang dihadapi atau memenuhi kebutuhan organisasi dan kebutuhan individu berkaitan dengan job performancenya. Tujuan sebaiknya ditulis secara spesifisik, sehingga mudah menilai hasil belajarnya. Dalam menuliskan tujuan, terdapat tiga komponen yang perlu diperhatikan yaitu kinerja tentang hal-hal apa yang mampu dilakukan pembelajar setelah mendapat pembelajaran, kondisi adalah batasan-batasan atau syarat-syarat suatu pencapaian kinerja yang melibatkan alat dan waktu, dan kriteria adalah pernyataan tentang kinerja apa yang diterima (Nadler, 1982; Piskurich, 2006; Sedarmayanti, 2007).

Sesuai dengan teori Critical Events Model (CEM), Nadler (1982) menyatakan bahwa setelah tujuan pelatihan ditulis, langkah berikutnya adalah melakukan evaluasi dan umpan balik. Tujuannya adalah untuk mengidentifikasi elemen-elemen yang harus dipertimbangkan dalam menetapkan tujuan program dan tujuan belajar secara operasional, menulis tujuan-tujuan program dan tujuan belajar yang terkait secara operasional.

\section{Tahap 5 Tahap Penyusunan Kurikulum}

Hasil penelitian menunjukkan bahwa dalam penyusunan kurikulum dilakukan oleh tim desainer P2SDM dan tim desainer P3G. Rumusan kurikulum telah disesuaikan dengan tujuan pelatihan dan jenis pelatihan. Beberapa hal yang juga menjadi bahan pertimbangan P2SDM dan P3G dalam perumusan kurikulum adalah sarana prasarana, tempat pelatihan, media pembelajaran, peserta pelatihan, kepakaran pemateri, jadwal, serta administrasi lainnya. Proses evaluasi dan umpan balik dilakukan untuk merefleksikan antara hasil rumusan kurikulum dengan tujuan yang telah ditetapkan sebelumnya. Bentuk evaluasi dan umpan balik melalui rapat koordinasi dengan para pimpinan dan tenaga profesional.

Hasil penilitian di atas sesuai dengan teori Critical Events Model (CEM) yang dikembangkan oleh Nadler (1982), bahwa yang pertama dilakukan desainer dalam merumuskan kurikulum adalah melihat kembali tujuan pembelajaran yang telah ditetapkan. Selanjutnya, mengidentifikasi materi atau teori pembelajaran untuk diimplementasikan dalam kurikulum. Perlu diperhatikan juga dalam kurikulum adalah pengalaman pembelajar, jenis instruktur, jarak antara instruktur, dan desainer. Kurikulum tersebut berkaitan dengan skill, sikap dan pengetahuan yang dibutuhkan oleh peserta pelatihan dalam meningkatkan job performance yang diharapkan oleh aorganisasi. Kegiatan terakhir dalam penyusunan kurikulum adalah membuat analisis hasil kerja penyusunan kurikulum untuk kemudian dievaluasi dan diberi umpan balik.

\section{Tahap 6 Penetapan Strategi Pembelajaran}

Tahap ini bertujuan untuk memilih strategi pembelajaran yang sesuai dengan kurikulum, peserta pelatihan, instruktur, dan organisasi. Berdasarkan hasil wawancara dengan Hs dan En ditemukan bahwa tahapan penetapan strategi pembelajaran ini dilakukan oleh tim desainer P2SDM dan P3G. Tim Desainer menetapkan metode pembelajaran telah disesuaikan dengan tujuan pelatihan, jenis pelatihan, materi pelatihan. Dalam hasil wawancaranya dengan desainer Hs bahwa yang menjadi pertimbangan pada event ini adalah kemudahan pelaksanaan, juga media pembelajaran, kesiapan peserta pelatihan, serta lamanya waktu yang digunakan.

Proses evaluasi dan umpan balik dilakukan dalam bentuk rapat tim dan konsultasi dengan pemateri. Nadler (1982) menyarankan bahwa keputusan dalam menetapkan strategi pembelajaran akan lebih akurat bila dilandasi oleh prinsip-prinsip psikologi pembelajaran, administrasi, budaya, instruktur dan peserta pelatihan. 


\section{Tahap 7 Penetapan Sumber-sumber Pelatihan}

Tim desainer menetapkan sumber mengacu pada kurikulum pelatihan, disesuaikan dengan kemampuan peserta, serta mengukur tingkat kemanfaatan alat-alat belajar. Di akhir tahap ini desainer melakukan proses evaluasi melalui rapat koordinasi bersama unit sarana prasana, dan BAUK. Hasil penilitian di atas sesuai dengan teori Critical Events Model (CEM) yang dikembangkan oleh Nadler (1982), langkah pertama yang perlu dilakukan adalah memastikan bahwa semua sumber daya yang diperlukan akan tersedia untuk program yang telah dirancang. Diantaranya memastikan ketersediaan sumber daya fisik misalnya peralatan, perlengkapan, ruang kelas. Ketersediaan anggaran, ketersediaan sumber daya manusia misalkan instruktur, penanggung jawab program atau pengarah, konsultan, peserta pelatihan dan kelengkapannya.

\section{Tahap 8 Persiapan Pelaksanaan Pelatihan}

Teori Critical Events Model (CEM) mempertegas bahwa tujuan dari tahapan ini adalah untuk melaksanakan program pelatihan sesuai dengan rencana yang telah disusun sebelumnya. Berdasarkan hasil wawancara dan observasi ditemukan bahwa tim panitia yang dibentuk oleh unit P2SDM dan unit P3G mempersiapkan dan melaksanakan tugas kepanitiannya. Pertama yang dilakukan oleh panitia adalah proses seleksi peserta. Peserta diseleksi tujuannya adalah agar tepat sasaran. Prioritas utama yang menjadi peserta adalah dosen yang muda-muda dan mahasiswa berdasarkan hasil tahap identifikasi kebutuhan dan berdasarkan hasil pemetaan dan pengkategoriannya.

Pada akhir tahap ini tim P2SDM dan P3G melakukan proses evaluasi melalui rapat bersama panitia, dan para pimpinan. Di akhir tahapan ini, perencana harus dapat merefleksikan sejauh mana hasil dari pelatihan telah memecahkan masalah awal dan mengidentifikasi adanya kebutuhan untuk mengulang program atau memodifikasinya (Nadler, 1982).

\section{Kekuatan dan Kelemahan Desain Pelatihan di IKIP Budi Utomo ditinjau dari Critical Event Model Leonard Nadler}

\section{Tahap 1 Kekuatan dan Kelemahan Identifikasi Kebutuhan Organisasi}

Berdasarkan hasil penelitian bahwa yang menjadi kekuatan pada tahap ini adalah adanya hasil evaluasi secara keseluruhan pelaksanaan pelatihan pada tahun sebelumnya menjadi acuan, tim desainer P2SDM dan tim P3G melibatkan unit penjaminan mutu dan BAUK, tim desainer mempresentasikan hasil analisis kebutuhan pada forum rapat pimpinan. Ditemukan ada kelemahan pada tahap ini yakni terletak pada hasilnya belum tampak dirincikan secara spesifik terkait kebutuhan-kebutuhan organisasi.

Kebutuhan organisasi dapat diidentifikasi dari masalah produksi atau layanan organisasi jika sumber masalahnya human error maka solusi alternatif pemecahannya melalui pelatihan, dapat diidentifikasi juga dari peralatan atau tata aturan, kebijakan, output, dan juga tekanan dari luar organisasi (Nadler, 1982).

\section{Tahap 2 Kekuatan dan Kelemahan Spesifikasi Pelaksanaan Tugas}

Berdasarkan hasil penelitian menunjukkan bahwa berdasarkan hasil analisis identifikasi kebutuhan penguatan keterampilan dosen maka pelatihan penyusunan bahan ajar menjadi alternatif solusi. Sementara pelatihan penyusunan PTK dan inovasi pembelajaran bagi mahasiswa menjadi tambahan modal keterampilan mengajar. Demikian juga, kurikulum pelatihan dan modul diperlukan ada pembaharuan. Keterbatasan sumber daya manusia menjadi titik lemah pada tahap ini, sehingga cukup butuh waktu dalam menganalisa dan mengklasifikasikan kebutuhan keterampilan tambahan yang dibutuhkan oleh dosen ataupun mahasiswa.

Dalam mengidentifikasi dan mengumpulkan data terdapat beberapa cara atau dapat memilih metode yang paling sesuai dengan kebutuhan, pekerjaan, dan organisasi. Sumber data dapat diperoleh dari karyawan, sejawat, atasan, dan pelanggan. Jenis data dapat berupa laporan dan arsip yang merupakan data tertulis baik yang tersimpan dalam komputer atau almari arsip, antara lain deskripsi kerja atau uraian tugas (Jones \& Wolters, 2008). 


\section{Tahap 3 Identifikasi Kebutuhan Pembelajar}

Hasil penelitian menunjukkan bahwa proses tahap identifikasi kebutuhan pembelajar dilakukan setelah tahap spesifikasi pelaksanaan tugas selesai artinya tidak diproses secara bersamaan, sasaran tahap ini adalah dosen muda yang juga berkewajiban melaksanakan tugas Tri Dharma Perguruan Tinggi, demikian juga untuk mahasiswa semester akhir sesuai jurusannya sebagai calon guru agar terampil pada saat mengajar dan profesional serta kompeten dibidang keilmuannya masing-masing. Sementara yang menjadi kelemahan pada tahap ini ditemukan hasil identifikasi kebutuhan pembelajarnya masih bersifat umum belum masuk ke hal yang lebih rinci.

Nadler (1982) mengklasifikasikan tiga bentuk kebutuhan diantaranya: (1) stated need, yaitu need yang timbul karena ada perbedaan antara job performance yang ada dengan job performance yang diharapkan; (2) implied need, yakni need yang timbul karena adanya perbedaan alat kerja atau perubahan sistem kerja atau pembaharuan teknologi; dan (3) field need, yakni need yang timbul dan dirasakan oleh pekerja. Kebutuhan atau needs yang diklasifikasikan oleh Leonard Nadler di atas dapat dijadikan dasar untuk memudahkan pemetaan dalam mengidentifikasi kebutuhan pembelajar.

\section{Tahap 4 Penetapan Tujuan}

Hasil penelitian menunjukkan bahwa tujuan pelatihan yang dirumuskan berdasarkan hasil analisis kebutuhan dan berdasarkan hasil diskusi dengan tenaga profesional yang ahli dalam penyusunan bahan ajar, tenaga profesional yang ahli dalam penyusunan proposal PTK dan inovasi pembelajaran. Tahap penetapan tujuan dirumuskan untuk mengakomodir semua kebutuhan pelatihan, kebutuhan peserta. Namun, pada tahap ini yang menjadi kelemahan desainer P2SDM mapun P3G tidak melibatkan delegasi dari calon peserta dalam penetapan tujuan.

Organisasi dalam menetapkan tujuan pelatihan disarankan agar tujuan-tujuan yang sudah ditulis dibagikan kepada supervisor, manajer, dan calon peserta pelatihan bila dimungkinkan (Mujiman, 2001), untuk mendapatkan pertimbangan apakah tujuan-tujuan tersebut sesuai dengan job performance yang diharapkan.

\section{Tahap 5, 6, dan 7 Penyusunan Kurikulum, Penetapan Strategi Pembelajaran dan Sumber- Sumber Pelatihan}

Hasil penelitian menunjukkan bahwa rumusan isi kurikulum sesuai dengan kebutuhan peserta, isi kurikulum sesuai dengan tujuan pelatihan yang telah ditetapkan. Penetapan strategi pembelajaran mengacu pada kompetensi yang akan dicapai oleh peserta. Penetapan sumber-sumber pelatihan tim desainer telah menyediakan list ketersediaan dan kesiapan fasilitas-fasilitas sumber pembelajaran, tim desainer mengkonsultasikan dengan pemateri terkait fasilitas pembelajaran yang dibutuhkan. Adapun yang menjadi kelemahan pada tahap ini yakni ditemukan pada tahap penyusunan kurikulum, penetapan strategi pembelajaran dan penetapan sumber pelatihan terkait kesulitan mencari instruktur yang bersertifikat widyaiswara, evaluasi dan umpan balik pada tiga tahapan tersebut belum maksimal. Evaluasi hanya melalui presentasi dokumen hasil penyusunan kurikulum pada forum rapat bersama para pimpinan.

Dalam CEM setiap event dilakukan evaluasi dan feedback, kecuali pada event identify the needs of organization. Evaluasi dan feedback dilaksanakan untuk meyakinkan bahwa apa yang dikerjakan berkaitan dengan kebutuhan organisasi. Pertanyaan-pertanyaan yang harus muncul pada waktu evaluasi dan feedback tahap penyusunan kurikulum apakah isi materi memenuhi tujuan-tujuan yang telah ditetapkan sebelumnya, apakah isi materi akan memenuhi kebutuhan individu yang teridentifikasi, apakah isi materi berkaitan dengan kebutuhan organisasi yang telah teridentifikasi sebelumnya. Evaluasi dan feedback tahap memilih strategi pembelajaran bertujuan untuk memilih strategi pembelajaran yang cocok dengan kurikulum, peserta pelatihan, instruktur dan organisasi. Sementara evaluasi dan feedback tahap penetapan sumber dapat diambil melalui beberapa pertanyaan yang berkaitan dengan ketersediaan anggaran, kesiapan fasilitas sarana prasarana, kesiapan instruktur, asisten instruktur, dan supervisor program pelatihan (Mujiman, 2001; Warsita, 2008). 


\section{Tahap 8 Persiapan Pelaksanaan Pelatihan}

Ditemukan beberapa kekuatan pada tahap ini diantaranya adalah adanya jadwal koordinasi persiapan pelaksanaan pelatihan, rapat koordinasi persiapan pelaksanaan pelatihan dilakukan antara tim panitia bersama para pimpinan, konfirmasi kesediaan pemateri dilakukan dua minggu sebelumnya, konfirmasi penggandaan makalah kepada pemateri dilakukan satu minggu sebelum pelaksanaan, tim panitia melakukan evaluasi persiapan pelaksanaan pelatihan dan berkoordinasi dengan ketua P2SDM, ketua P3G, BAUK, dan unit terkait. Kelemahan pada tahap ini ditemukan bahwa panitia tidak mengecek ulang kualifikasi peserta apakah peserta memenuhi syarat atau tidak.

Peserta pelatihan yang relevan mengikuti suatu pelatihan adalah peserta pelatihan yang sudah diseleksi dan punya motivasi belajar untuk merubah atau meningkatkan job performance dalam rangka mengatasi problem organisasi (Mujiman, 2001). Dapat ditarik kesimpulan pada tahap pelaksanaan ini menyeleksi calon peserta yang telah teridentifikasi sebelumnya sangat dibutuhkan sehingga pada akhirnya pelaksanaan pelatihan akan dapat berjalan lancar dan tentu hasilnya dapat membantu bagi peserta itu sendiri dan lembaga.

\section{Penyebab Kekuatan dan Kelemahan Desain Pelatihan di IKIP Budi Utomo ditinjau dari Critical Event Model Leonard Nadler}

Tahap 1 Penyebab Kekuatan dan Kelemahan Identifikasi Kebutuhan Organisasi

Dalam penelitian ini ditemukan faktor penyebab kekuatan tahap identifikasi kebutuhan organisasi diantaranya adalah selalu mengirimkan staf pada kegiatan-kegiatan pelatihan, termasuk pelatihan penyusunan bahan ajar, pelatihan penyusunan proposal PTK, dan seminar inovasi pembelajaran. Dalam mendesain pelatihan penyusunan bahan ajar dosen, penyusunan PTK, pelatihan inovasi pembelajaran desainer melibatkan tenaga profesional yang ahli dibidangnya serta didukung oleh ketersediaan anggaran. Adapun faktor penyebab kelemahannya yakni desainer dalam mendiagnosis data dan informasi yang diperoleh dari unit penjaminan mutu dianalisa hanya bagian luarnya saja.

Nadler (1982) menjelaskan bahwa kebutuhan dalam organisasi dapat muncul dari masalah produksi atau pelayanan, peralatan, kebijakan, hasil (output), maupun tekanan-tekanan dari luar organisasi. Dessler (2000) yang menyatakan bahwa analisis kebutuhan pelatihan bagi karyawan merupakan sesuatu yang kompleks karena harus memutuskan apakah pelatihan merupakan suatu solusi atas permasalahan atau bukan. Analisis kebutuhan pelatihan tersebut menurut Dessler dibedakan menjadi dua, yaitu analisis tugas dan analisis kinerja. Analisis tugas digunakan untuk memepertimbangkan pelatihan yang dibutuhkan oleh karyawan baru, sementara analisis kinerja untuk mendeskripsikan defisiensi kinerja dan menentukan apakah efisiensi tersebut dapat diperbaiki melalui pelatihan atau solusi lain (Dessler, 2009).

\section{Tahap 2 Penyebab Kekuatan dan Kelemahan Tahap Spesifikasi Pelaksanaan Tugas}

Koordinasi antara tim desainer P2SDM dengan unit kepegawaian, dan unit penjaminan mutu dalam mengolah dan memetakan keterampilan-keterampilan dosen menjadi faktor penyebab kekuatan pada tahap ini. Sesuai dengan pendapat Nadler bahwa dalam mengumpulkan data dikumpukan dari berbagai pihak dalam organisasi calon peserta pelatihan untuk memperoleh gambaran mengenai pekerjaanpekerjaan yang akan ditingkatkan pencapaiannya melalui pelatihan, menentukan teknik, waktu, sumber pengumpulan data dalam melakukan spesifikasi performa pekerjaan organisasi calon peserta pelatihan, dan melakukan evaluasi dan umpan balik terhadap spesifikasi performa pekerjaan yang telah dilakukan (Nadler, 1982). Sementara yang menjadi faktor penyebab kelemahan pada tahap ini adalah terbatasnya SDM baik tim desainer d unit P2SDM maupun dari P3G. Disarankan oleh Efendi agar menggunakan metode yang efektif dan efisien.

\section{Tahap 3 Penyebab Kekuatan dan Kelemahan Tahap Identifikasi Kebutuhan Pembelajar}

Hasil penelitian menunjukkan bahwa yang menjadi faktor penyebab kekuatan pada tahapan ini adalah adanya tim desainer dalam mengumpulkan data beracuan pada hasil data tahap spesifikasi pelaksanaan 
tugas yakni tahap sebelumnya, tim desainer mengidentifikasi kebutuhan pembelajar melalui wawancara non formal dengan dosen muda dan mahasiswa semester akhir sebagai calon peserta pelatihan. Di dalam CEM disebutkan bahwa identifikasi kebutuhan pembelajar dilakukan dengan cara mengumpulkan data kebutuhan pembelajar (Nadler, 1982).

Metode pengumpulan data identifikasi kebutuhan pembelajar dapat memilih melalui wawancara. Jika wawancara yang dipilih sebagai metode maka disarankan oleh Nadler wawancara harus spesifik mungkin. Adapun yang menjadi faktor penyebab kelemahan tahap identifikasi kebutuhan pembelajar ini adalah bahwa data yang terlacak dari unit penjaminan mutu yang berkaitan dengan pengembangan diri dosen dan pengembangan keterampilan mengajar sebagai calon guru bagi mahasiswa semester akhir berupa data masih bersifat umum belum diidentifikasi secara rinci penyebab-penyebanya, misal penyebab masih rendahnya buku ajar yang disusun oleh dosen tidak diuraikan secara rinci.

Setelah data kebutuhan pembelajar dikumpulkan, maka langkah selanjutnya adalah membuat daftar kebutuhan pembelajar. Daftar kebutuhan dapat dihasilkan dengan metode substraksi dimana kebutuhan diperoleh melalui selisih atau perbedaan antara performa pekerjaan yang diharapkan dipahami karyawan dengan yang dilakukan secara riil. Langkah selanjutnya adalah membuat analisis kebutuhan pembelajar yang spesifik dan melakukan evaluasi dan umpan balik terhadap terhadap analisis kebutuhan pembelajar yang telah disusun. Hasil analisis tersebut kemudian dikirimkan kepada pihak yang bersangkutan seperti atasan dan bawahan calon peserta pelatihan untuk dimintai umpan balik.

\section{Tahap 4 Penyebab Kekuatan dan Kelemahan Tahap Penetapan Tujuan}

Koordinasi dan analisis data tim desainer P2SDM dan tim desainer P3G bersama unit kepagawaian dan unit penjaminan mutu telah menghasilkan kebutuhan-kebutuhan pembelajar yakni jenis program pelatihan dan materi menjadi faktor penyebab kekuatan pada tahap ini. Sesuai dengan pendapat Nadler bahwa aktivitas pertama yang harus dilakukan adalah membuat daftar prioritas kebutuhan organisasi dan pembelajar berdasarkan hasil kegiatan tahapan CEM sebelumnya (Nadler, 1982). Sementara yang menjadi faktor penyebab kelemahan pada tahap ini berdasarkan hasil penelitian menunjukkan bahwa dalam perumusan tujuan tidak melibatkan secara langsung perwakilan calon peserta baik dari dosen maupun mahasiswa.

Setelah tujuan pelatihan dan pembelajaran ditulis, langkah selanjutnya adalah melakukan evaluasi dan umpan balik. Evaluasi dan umpan balik dilakukan dengan melibatkan para atasan, pemegang kebijakan, maupun calon peserta pelatihan jika memungkinkan. Hasil akhir dari kegiatan evaluasi dan umpan balik terhadap penetapan tujuan harus dapat menjawab pertanyaan mengenai apakah tujuan program pelatihan dapat diterima, apakah tujuan belajar dapat diterima, apakah semua kebutuhan telah tercermin dalam tujuan, apakah prioritas tujuan pembelajaran dapat diterima, apakah tujuan-tujuan tersebut berkaitan dengan "spesifikasi performa pekerjaan, dan apakah tujuan-tujuan tersebut dapat dipenuhi secara internal ataupun eksternal melalui pelatihan (Nadler, 1982).

\section{Tahap 5, 6, dan 7 Penyebab Kekuatan dan Kelemahan Penyusunan Kurikulum, Penetapan Strategi Pembelajaran dan Sumber-sumber Pelatihan}

Secara berurutan hasil penelitian ini menunjukkan bahwa yang menjadi faktor penyebab tahapan ini diantaranya adalah desainer baik dari P2SDM maupun P3G dalam menyusun kurikulum mendatangkan dosen senior yang ahli dibidang pengembangan kurikulum, penyusun kurikulum telah memilih metode yang tepat dan telah mempertimbangkan karakteristik pembelajar dalam pelatihan penyusunan bahan ajar dosen, dan pelatihan penyusunan PTK serta pelatihan inovasi pembelajaran bagi mahasiswa, penyusun kurikulum pelatihan dalam merumuskan kurikulum mengacu pada tujuan pelatihan yang telah ditetapkan sebelumnya. Nadler (1982) menguatkan yang pertama dilakukan dalam penyusunan kurikulum adalah melihat kembali tujuan pembelajaran yang telah ditetapkan sebelumnya. Selanjutnya, dipilih teori pembelajaran untuk diimplementasikan dalam kurikulum. Kurikulum juga harus memperhatikan variabel-variabel penting seperti pengalaman pembelajar, jenis instruktur, dan geografi atau jarak antara instruktur dan desainer (Nadler, 1982).

Faktor penyebab kekuatan tahap penetapan strategi pembelajaran ditemukan sebagai beriku; latar belakang bidang keilmuan dosen sebagai calon peserta pelatihan penyusunan bahan ajar dijadikan dasar 
penetapan strategi pembelajaran. Demikian juga latar belakang bidang keilmuan mahasiswa dijadikan dasar dalam penetapan strategi pembelajaran pelatihan PTK dan inovasi pembelajaran. Desainer telah menkonsultasikan hasil strategi pembelajaran dengan narasumber.

Faktor penyebab kekuatan tahap penetapan sumber-sumber pelatihan bahwa dalam penetapan sumber-sumber pelatihan ini baik dari desainer P2SDM maupun P3G mengikuti alur yang berlaku, untuk pengurusan sumberdaya fisik berkoordinasi dengan unit sarana prasarana dengan mengacu pada pelatihan sebelumnya, sementara yang berkaitan dengan sumber daya keuangan koordinasi unit BAUK dan mengacu pada perencanaan awal tahun. Sebelum pelaksanaan pelatihan desainaer melakukan pemeriksaan kesiapan dan ketersediaan sumber-sumber di atas. Panitia telah menyiapkan segala bentuk administrasi yang dibutuhkan dengan membuat form pengecekan.

Faktor penyebab kelemahan tahap ini secara berurutan sebagai berikut; pada tahap penyusunan kurikulum desainer agak kesulitan mencari tim pakar yang ahli dalam menyusun kurikulum pelatihan. Dengan bantuan tim pakar paling tidak memudahkan desainer mengkategorisasikan mana yang termasuk kedalam materi essensial, materi helpful, materi peripheral, dan materi unrelated. Langkah selanjutnya dalam penyusunan kurikulum adalah memilih ahli muatan kurikulum. Apabila anggaran memungkinkan, ahli kurikulum dapat disewa dari luar luar organisasi, namun jika kurang memungkinkan, maka dapat memakai tenaga dalam organisasi sendiri. Jika berasal dari dalam organisasi, para ahli muatan (Subject Matter Specialist/SMS) dapat berasal dari atasan, staf yang telah memiliki pengalaman belajar di bidang yang sama dengan program pelatihan yang akan dikembangkan, atau staf bagian pengembangan sumber daya manusia yang khusus berperan sebagai ahli muatan. Jika ahli muatan berasal dari pihak eksternal organisasi, maka dapat berasal dari vendor atau konsultan, perguruan tinggi, tenaga perorangan, atau organisasi profesi (Nadler, 1982).

Pada Tahap penetapan strategi pembelajaran desainer belum banyak mempertimbangkan karakter instruktur karena belum memiliki daftar instruktur yang bersertifikat. Disarankan oleh Nadler bahwa yang pertama dilakukan dalam menetapkan strategi pembelajaran adalah meminta bantuan tenaga profesional berpengalaman untuk memilih strategi pembelajaran. Yang kedua adalah memastikan ketersediaan fasilitas pembelajaran yang sesuai dengan strategi pembelajaran yang akan dipilih, mempertimbangkan budaya organisasi pembelajar, dan mendapatkan gambaran instruktur yang sesuai dengan strategi pembelajaran (Nadler, 1982).

Pada tahap penetapan sumber-sumber pelatihan koordinasi panitia dengan unit sarana prasarana tidak maksimal. Panitia tidak melampirkan cek list ketersediaan dan kesiapan fasilitas pada surat permohonan menggunakan tempat pelatihan. Nadler (1982) menyarankan agar membuat daftar tilik sumber-sumber pelatihan yang dibutuhkan. Caranya adalah dengan menjawab sejumlah pertanyaan. Untuk masalah sumber daya pelatihan, pertanyaan dalam ceklis adalah mengenai siapa yang akan mengajar, apakah instruktur yang direncanakan dapat hadir, apakah instruktur yang ditunjuk membutuhkan persiapanpersiapan tertentu sebelum mengajar seperti meminta rencana pembelajaran, mengikuti pelatihan untuk instruktur, dan sebagainya, serta apakah pembelajar yang dipilih dapat mengikuti pelatihan.

\section{Tahap 8 Penyebab Kekuatan dan Kelemahan Tahap Persiapan Pelaksanaan Pelatihan}

Berdasarkan hasil penilitian menunjukkan bahwa yang menjadi faktor penyebab kekuatan pada tahap ini adalah Tim desainer dari P2SDM dan P3G menjelang pelaksanaan pelatihan berkali-kali mengadakan rapat koordinasi dengan melibatkan banyak pihak, Undangan disampaikan kepada peserta selain dikirim melalui undangan fisik, juga melalui media sosial seperti email, dan WA. Menjelang pelaksanaan pelatihan semua fasilitas yang dibutuhkan dalam ruangan telah diperiksa kelengkapannya. Memastikan kembali kehadiran narasumber sesuai jadwal. Melakukan koordinasi terakhir persiapan pelaksanaan pelatihan. Adapun faktor penyebab kelemahan pada tahap ini panitia hanya menyediakan daftar hadir sebagai bentuk kontrol kehadiran peserta.

Hal yang berkaitan dengan rencana pelaksanaan kegiatan melibatkan: (1) mempersiapkan instruktur maupun instruktur pengganti; (2) mempersiapkan peralatan dan perlengkapan dan antisipasi masalah seperti kekeliruan perlengkapan, fotokopi materi yang tidak mencukupi, dan peralatan tidak berfungsi; (3) mempersiapkan penanggung jawab program melakukan kunjungan secara periodik ke kelas untuk 
memastikan kegiatan berjalan lancar sesuai rencana; dan (4) mempersiapkan ketahanan fokus peserta pelatihan terhadap pembelajaran (Nadler, 1982).

Langkah selanjutnya adalah membuat analisis kegiatan mempersiapkan pelaksanaan pelatihan. Hal-hal yang muncul dalam analisis desainer adalah hal-hal yang dilakukan dalam pelaksanaan pelatihan sepertihal-hal yang dipelajari peserta,dampak pelatihan terhadap perubahan performa kinerja, rekomendasi peningkatan program pelatihan, dan peninjauan ulang terhadap seluruh tahapan desain pelatihan yang telah dilaksanakan (Nadler, 1982).

\section{SIMPULAN}

Desain pelatihan yang disusun di IKIP Budi Utomo Malang sesuai dengan sembilan komponen yang ditetapkan oleh Leonard Nadler dalam CEM. Kekuatan: sistematika desain yang disusun di IKIP Budi Utomo Malang sesuai dengan pola pikir CEM Leonard Nadler. Kelemahan: Tahap 1 indentifikasi kebutuhan secara spesifik belum digali lebih dalam; Tahap 2 ditemukan keterbatasan sumber daya manusia; Tahap 3 yang teridentifikasi masih bersifat umum belum rinci; Tahap 4 tidak melibatkan calon peserta; Tahap 5, 6, dan 7 kesulitan mencari instruktur bersertifikat widyaiswara; Tahap 8 panitia tidak mengecek ulang kualifikasi peserta.

Faktor penyebab kekuatan dan kelemahan: Tahap 1 delegasi staf ke berbagai pelatihan, melibatkan tenaga profesional, ketersediaan anggaran. Penyebab kelemahannya; desainer belum mendiagnosis data dan informasi secara mendalam. Tahap 2 adanya koordinasi antara tim desainer dengan unit terkait, penyebab kelemahannya; terbatasnya SDM. Tahap 3 hasil data tahap spesifikasi pelaksanaan tugas dijadikan acuan tahap identifikasi kebutuhan pembelajar. Penyebab kelemahan; hasil identifikasi kebutuhan pembelajar masih bersifat umum belum teridentifikasi penyebab-penyebanya. Tahap 4 adanya koordinasi dan analisis data tim desainer bersama unit terkait. Penyebab kelemahan; perumusan tujuan tidak melibatkan calon peserta.

Tahap 5, 6, dan 7 dalam menyusun kurikulum mendatangkan dosen senior yang ahli di bidang pengembangan kurikulum, pemilihan metode yang tepat dan mempertimbangkan karakteristik pembelajar, perumusan kurikulum mengacu pada tujuan pelatihan, penetapan strategi pembelajaran didasarkan pada latar belakang keilmuan calon peserta, desainer menkonsultasikan hasil strategi pembelajaran dengan narasumber, penetapan sumber mengikuti alur yang berlaku. Penyebab kelemahan tahap ini secara berurutan sebagai berikut; kesulitan mencari tim pakar yang ahli dalam menyusun kurikulum pelatihan, desainer, panitia tidak melampirkan ceck list ketersediaan dan kesiapan fasilitas. Tahap 8 koordinasi dengan pihak terkait dan memeriksa kelengkapan fasilitas, undangan dikirim melalui undangan fisik, email, dan WA, memastikan kehadiran narasumber, koordinasi terakhir persiapan pelaksanaan pelatihan. Penyebab kelemahan pada tahap ini panitia hanya menyediakan daftar hadir sebagai bentuk kontrol kehadiran peserta.

\section{DAFTAR RUJUKAN}

AECT. (2004). AECT Definition and Terminology Committee Document: The Meanings of Educational Technology, (Online), (http://www.indiana.edu/), diakses 1 September 2019.

ASTD. (2008). Train The Trainer Guide: Instructional Design and Implementation: The Tools for Creating Training Program Curriculum. Denvers: ASTD Press.

Boise State University. (2008). Edtech 575: Integrating Technology into the Classroom Curriculum Alignment with AECT Standards, (Online), (http://edteki.com/courses/EDTECH581/course_documents/581syllabus. htm), diakses 1 September 2019.

Burkhardt, H. (2009). On Strategic Design. Journal of Educational Designer, 1(3), 1-9.

Denzin, N. K., \& Lincoln, Y. S. (2009). Handbook of Qualitative Research. Terjemahan oleh Dariyatno. Yogyakarta: Pustaka Pelajar.

Dessler, G. (2000). Human Resource Management. New Jersey: Prentice Hall, Inc. 
Dessler, G. (2009). Manajemen Sumber Daya Manusia. Jakarta: Index.

Dunning, J. (2007). Teaching the System Approach to Training through Case Analysis. Journal of Human Resources Education, 1(3), 13-36.

Furjanic, S. W., \& Trotman, L. A. (2000). Turning Training Into Learning. New York: Amacom.

Goldstein, I. L., \& Ford, J. K. (2002). Training in Organizations. Belmont: Wadsworth Group.

Gusdorf, M. L. (2009). Training Design, Development and Implementation. Alexandria: Society for Human Resource Management.

Ivancevich, J. M. (2008). Perilaku dan Manajemen Organisasi. Jakarta: Erlangga.

Jones, J. J, \& Walters, D. L. (2008). Human Resource Management in Education. Yogyakarta: Q-Media.

Morrison, G., Rose, S. M., \& Kalman, H. K. (2011). Designing Effective Instruction. Denvers: John Wiley and Sons, Inc.

Mujiman, H. (2001). Manajemen Pelatihan Berbasis Belajar Mandiri. Yogyakarta: Pustaka Pelajar.

Nadler, L. (1982). Designing Training Program: The Critical Events Model. Philippines: Addison-Wesley Publishing Company, Inc.

Noe, A. R., Hollenbeck, J. R., \& Gerhart, B. (2000). Human Resource Management: Gaining Competitive Advantage. Boston: McGraw-Hill Companies, Inc.

Piskurich, G. M. (2006). Rapid Instructional Design: Learninng ID Fast and Right. San Fransisco: John Wiley and Son, Inc.

Sedarmayanti. (2007). Manajemen Sumber Daya Manusia, Reformasi Birokrasi dan Manajemen Pegawai Negeri Sipil. Bandung: PT Refika Aditama.

Smith, E. (2009). A Review of Twenty Years of Competency-Based Training in the Australian Vocational Education and Training System. International Journal of Training and Development, 14(3), 54-64.

Warsita, B. (2008). Teknologi Pembelajaran: Landasan dan Aplikasinya. Jakarta: PT Rineka. Cipta.

Watson, S. L., \& Reigeluth, C. M. (2011). System Design for Change in Education and Training, (Online), (www. aect.org/edtech/edition3/ER5849X_COS2.fm.pdf), diakses 1 September 2019. 